\title{
Dental, skeletal and soft tissue effects of the Distal Jet appliance: A prospective clinical study
}

Rachelle Simões Reis', José F. C. Henriques', Guilherme Jansonn', Karina Maria Salvatore Freitas², Wilana Moura ${ }^{1}$

DOI: https://doi.org/10.1590/2177-6709.24.6.056-064.oar

Objective: This study evaluated the dental, skeletal and soft tissue effects in Class II malocclusion patients treated with Distal Jet appliance, compared to an untreated control group. Methods: 44 patients with Class II malocclusion were divided into two groups: Group 1 (experimental) - 22 patients, mean age of 12.7 years, treated with the Distal Jet appliance for a mean period of 1.2 years; Group 2 (control) - 22 untreated patients, mean age of 12.2 years, followed by a mean period of 1.2 years. Lateral cephalograms were obtained before treatment $\left(\mathrm{T}_{0}\right)$ and at the end of the distalization $\left(\mathrm{T}_{1}\right)$.Independent $t$ test was used to identify intergroup differences. Results: When compared to control group, the Distal Jet produced a significant increase in mandibular plane angle $\left(0.7 \pm 2.0^{\circ}\right)$. The maxillary second molars presented distal inclination $\left(6.6 \pm 3.8^{\circ}\right)$, distalization $(1.1 \pm 1.1 \mathrm{~mm})$ and extrusion $(1.3 \pm 2.1 \mathrm{~mm})$. The maxillary first molars distalized by $1.2 \pm 1.4 \mathrm{~mm}$. The maxillary first premolars mesialized by $3.4 \pm 1.1 \mathrm{~mm}$. The maxillary incisors showed slight labial tipping of $4.3 \pm 4.7^{\circ}$ and were protruded by $2.4 \pm 1.7 \mathrm{~mm}$. There were no significant changes in the facial profile. The overjet increased $1.5 \pm 1.1 \mathrm{~mm}$ and overbite had no significant changes. Conclusion: The Distal Jet appliance is effective to distalize the maxillary first molars, but promotes increase in mandibular plane angle, distal inclination, extrusion and distalization of maxillary second molars, mesialization of maxillary first premolars, proclination and protrusion of maxillary incisors, and increase in overjet, when compared to a control group.

Keywords: Orthodontic appliance. Orthodontics, corrective. Malocclusion, Angle Class II.

Objetivo: o presente estudo avaliou os efeitos dentoesqueléticos e tegumentares em pacientes com má oclusão de Classe II tratados com aparelho Distal Jet, comparando-os com um grupo controle não tratado. Métodos: 44 pacientes com má oclusão de Classe II foram divididos em dois grupos: Grupo 1 (experimental) - 22 pacientes, idade média de 12,7 anos, tratados com o aparelho Distal Jet por um período médio de 1,2 anos; Grupo 2 (controle) - 22 pacientes não tratados, idade média de 12,2 anos, acompanhados por um período médio de 1,2 anos. Telerradiografias laterais foram obtidas antes do tratamento $\left(\mathrm{T}_{0}\right)$ e no final da distalização $\left(\mathrm{T}_{1}\right)$. O teste $t$ independente foi usado para identificar as diferenças entre os grupos. Resultados: quando comparado ao grupo controle, o Distal Jet produziu um aumento significativo no ângulo do plano mandibular $\left(0,7 \pm 2,0^{\circ}\right)$. Os segundos molares superiores apresentaram inclinação distal $\left(6,6 \pm 3,8^{\circ}\right)$, distalização $(1,1 \pm 1,1 \mathrm{~mm})$ e extrusão $(1,3 \pm 2,1 \mathrm{~mm})$. Os primeiros molares superiores foram distalizados por $1,2 \pm 1,4 \mathrm{~mm}$. Os primeiros pré-molares superiores, mesializados por $3,4 \pm 1,1 \mathrm{~mm}$. Os incisivos superiores mostraram leve inclinação labial de $4,3 \pm 4,7^{\circ} \mathrm{e}$ foram protruídos por $2,4 \pm 1,7 \mathrm{~mm}$. Não existiram alterações significativas no perfil facial. O overjet aumentou 1,5 $\pm 1,1 \mathrm{~mm}$, e o overbite não sofreu alterações significativas. Conclusão: o aparelho Distal Jet é eficaz para distalizar os primeiros molares superiores, mas promove aumento no ângulo do plano mandibular, inclinação distal, extrusão e distalização dos segundos molares superiores, mesialização dos primeiros pré-molares superiores, vestibularização e protrusão dos incisivos superiores e aumento do overjet, quando comparado a um grupo de controle.

Palavras-chave: Aparelho ortodôntico. Ortodontia corretiva. Má oclusão Classe II de Angle.

${ }^{1}$ Universidade de São Paulo, Faculdade de Odontologia de Bauru, Departamento de Ortodontia (Bauru/SP, Brazil).

${ }^{2}$ Centro Universitário Ingá, Departamento de Ortodontia (Maringá/PR, Brazil).

» Patients displayed in this article previously approved the use of their facial and intraoral photographs.

» The authors report no commercial, proprietary or financial interest in the products or companies described in this article.
How to cite: Reis RS, Henriques JFC, Janson G, Freitas KMS, Moura W. Dental, skeletal and soft tissue effects of the Distal Jet appliance: A prospective clinical study. Dental Press J Orthod. 2019 Nov-Dec;24(6):56-64. DOI: https://doi.org/10.1590/2177-6709.24.6.056-064.oar

Submitted: June 16, 2018 - Revised and accepted: November 25, 2018

Contact address: Karina Maria Salvatore de Freitas

Universidade de São Paulo, Faculdade de Odontologia de Bauru, Departamento de Ortodontia - Alameda Octávio Pinheiro Brisolla 9-75, Bauru/SP

CEP: 17.012-901 -E-mail: kms@@uol.com.br 


\section{INTRODUCTION}

There are several mechanisms for molar distalization, including intraoral distalizer appliances such as the Distal Jet appliance. These appliances can be used with conventional and skeletal anchorage. ${ }^{1-6}$ According to Cozzani et al, ${ }^{7}$ when the Distal Jet with skeletal anchorage was compared with the Distal Jet with conventional anchorage, the mean molar distalization and treatment time were similar.

Skeletal anchorage devices have easy installation and can be used with intraoral distalizer to control undesirable side effects. However, these devices cannot be used in all cases, for several factors as failure of the miniscrews, no patient acceptance due to surgical procedure necessary to installation, or by the presence of systemic disorder. ${ }^{8-11}$ In these cases, the orthodontist should use intraoral distalizer with conventional anchorage.

Kinzinger et $\mathrm{a}^{12}$ performed a systematic review to compare the efficiency of various appliance types with intramaxillary anchorage for molar distalization. The authors observed that the First Class and the Distal Jet appliances are more efficient than the Jones Jig appliance for molar distalization.

The mechanisms for molar distalization with intraoral conventional anchorage are considered a practical resource for anteroposterior correction, since these appliances promote more space gain in the maxillary arch and correct the Class II molar relationship with reduced need of patient compliance..$^{6,13-18}$

The dental, skeletal and soft tissue effects of Distal Jet appliance were evaluated by some studies, ${ }^{16-21}$ but only the study of Vilanova et a ${ }^{21}$ compared the effects with a control group; however, the study evaluated the effects of the Distal Jet appliance followed by fixed appliances, thus more studies are necessary. Therefore, this study aimed to evaluate the dental, skeletal and soft tissue effects in treatment of Class II malocclusion with the use of the Distal Jet appliance, comparing to an untreated control group.

\section{MATERIAL AND METHODS Material}

This prospective study was approved by the ethics in research committee of Bauru Dental School, University of São Paulo, Brazil (protocol num- ber: 1462004). The parents or legal guardians of all patients signed an informed consent allowing treatment to be performed.

The sample size was calculated based on an alpha significance level of 0.05 and a beta of 0.2 to achieve $80 \%$ of power to detect a mean difference of $1.6 \mathrm{~mm}$ with a standard deviation of 1.84 in the 6-PTV changes after the distalization with the Distal Jet appliance, between the groups. ${ }^{22}$ The sample size calculation showed that $22 \mathrm{pa}-$ tients were needed in each group.

The sample consisted of 44 patients with Class II malocclusion divided into two groups. Group 1 (experimental) - 22 patients (5 male; 17 female), at a mean age of 12.7 years $(\mathrm{SD}=1.2$, range 10.5 to 14.7 years), treated with the Distal Jet appliance. These patients were prospectively treated at the Bauru Dental School, by the same orthodontist. All patients presented the germen of the maxillary third molars and the maxillary second molars erupted at the beginning of treatment. Four patients presented $1 / 4$ cusp Class II molar relationship, 16 presented $1 / 2$ cusp Class II and 2 presented $3 / 4$ cusp Class II molar relationship. Patients of Group 1 were selected in Orthodontic Department of Bauru Dental School to treatment according to the following inclusion criteria.

»Class II malocclusion, division 1 or 2.

"Absence of transversal discrepancies.

" Minimal or no crowding in the mandibular arch.

"Permanent dentition.

» FMA angle smaller than $31^{\circ}$.

"Non-extraction treatment.

"Balanced facial profile.

Group 2 (control) - 22 subjects (11 male; 11 female), at a mean age of 12.2 years $(\mathrm{SD}=0.8$, range 11.0 to 14.7 years) obtained from the files of the same Orthodontic Department, who did not receive any orthodontic treatment. The control group was an untreated historical control group selected in order to match the experimental group, according to the inclusion criteria. Initial ages and observation time were matched between the groups. Besides, sex distribution in the groups was also matched. The type of malocclusion was Class II, the same as the experimental group, and the severity of this malocclusion was also 
matched between the two groups. Good-quality radiographs with adequate landmark visualization were used to select the Group 2. In control group, all patients presented the germen of the maxillary third molars, too.

All patients in the experimental group received a Distal Jet appliance (American Orthodontics, Sheboygan, Wisconsin) proposed by Carano and $\operatorname{Testa}^{23}$ (Fig 1).Bands were fitted on the maxillary first molars and maxillary first premolars, and then the maxillary dental casts were sent to the laboratory for appliance construction. Coil springs were activated every 4 to 6 weeks. The forces generated by the NiTi coils were of $240 \mathrm{~g}$.

Eighty-eight lateral cephalograms were taken for the study. Cephalometric headfilms were collected at the beginning $\left(\mathrm{T}_{0}\right)$ and at the end of the Distal Jet appliance treatment $\left(\mathrm{T}_{1}\right)$. The mean time period between the initial $\mathrm{T}_{0}$ radiograph and the post-treatment $T_{1}$ radiograph was 1.2 years
$(\mathrm{SD}=0.3$, range 0.6 to 1.6 years $)$. Figure 2 illustrates a maxillary molar distalization and final results after use of the Distal Jet appliance.

\section{Statistical analyses}

Lateral cephalograms were evaluated after one month interval and casual and systematic error study was performed. Comparability between the groups regarding sex distribution and malocclusion severity were performed with chi-square tests and comparability of initial and final ages, treatment/observation periods and pretreatment cephalometric variables were performed with independent $t$ tests. Intergroup changes of each variable from $T_{0}$ to $T_{1}$ were statistically analyzed with independent $t$ tests.

Statistical analyses were performed with Statistica for Windows software (version 6.0, StatSoftInc, Oklahoma, USA). Differences with a probability of error less than $5 \%(p<0.05)$ were considered statistically significant.

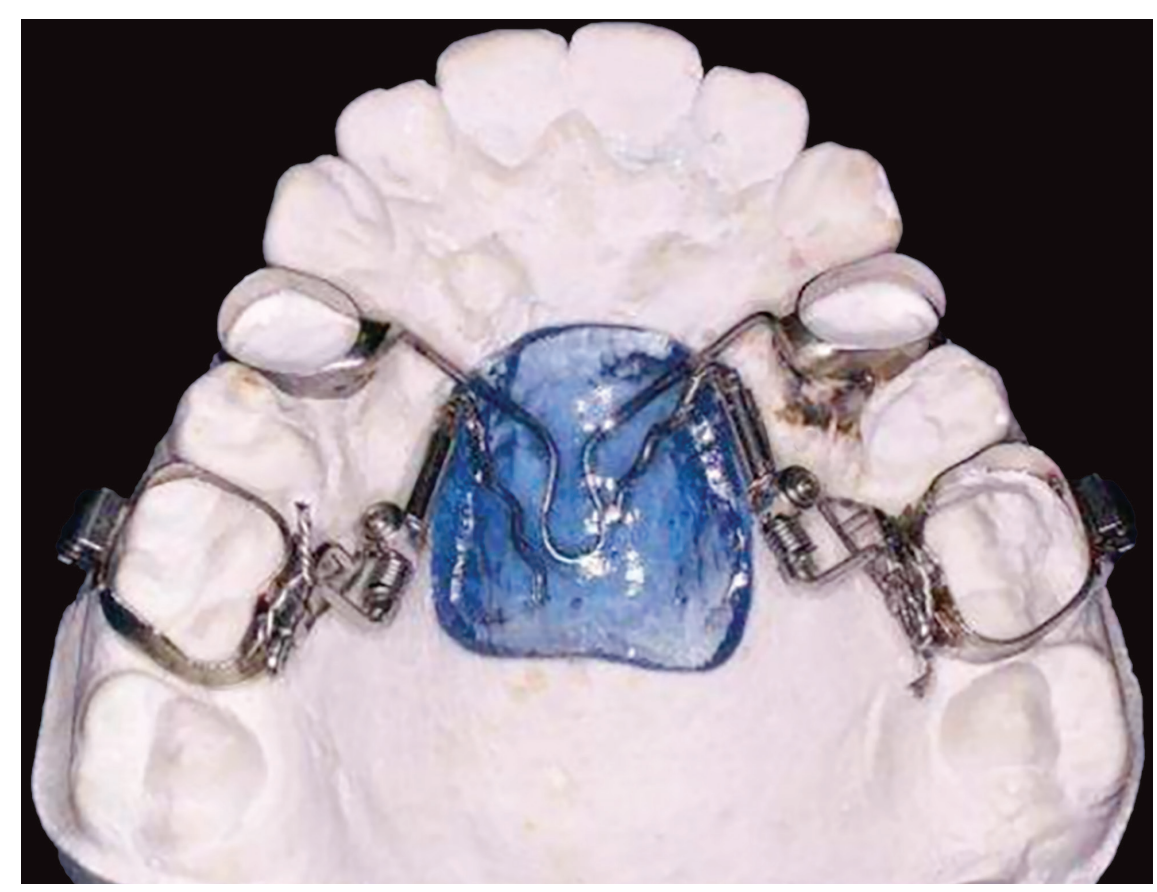

Figure 1 - Distal Jet appliance. 

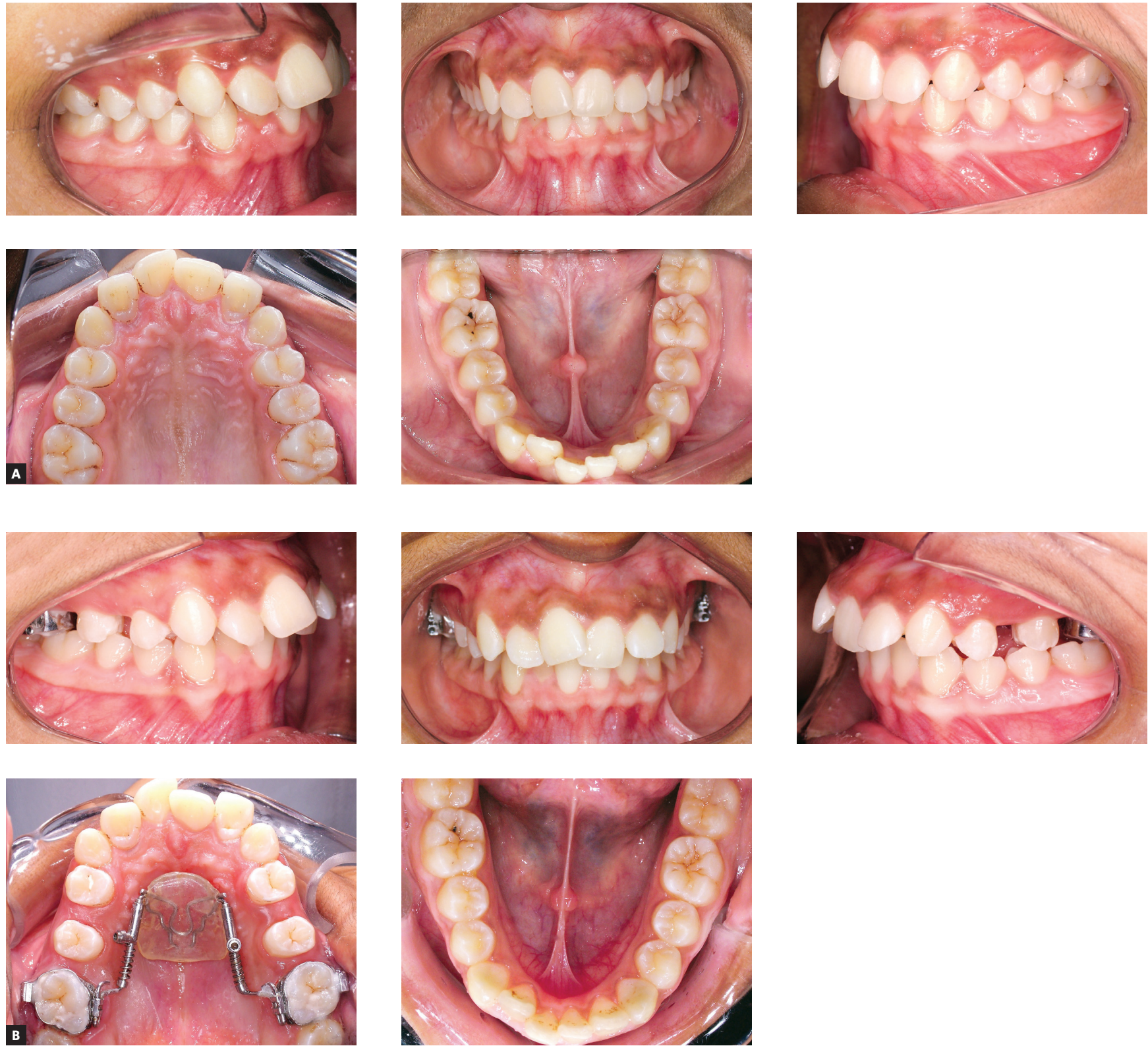

Figure 2 - Maxillary molar distalization and final results after use Distal Jet appliance: A) initial; B) final.

\section{RESULTS}

The casual errors varied from $0.28 \mathrm{~mm}$ (E-LL) to $0.77 \mathrm{~mm}(\mathrm{Co}-\mathrm{Gn})$ and from $0.33^{\circ}$ (SN.Gn) to $2.61^{\circ}$ (NLA), and only four of the thirty variables presented systematic errors (SNB, 7-PTV, 7-PP, 4-PP).

The groups were comparable regarding initial and final ages, treatment/observation period, sex distribution and malocclusion severity. Cephalometrically, at pretreatment only two variables (-PTV - higher in experimental group and 6. SN - higher in control group) were significantly different between the groups (Tables 1 and 2).
Skeletal assessments showed that the cranial base remained constant in both groups. The mandibular plane angle increased significantly in experimental group $\left(0.7 \pm 2.0^{\circ}\right)$ and reduced in control group $\left(-0.7 \pm 1.5^{\circ}\right)$. In experimental group, the maxillary second molars showed significant distal inclination $\left(-6.6 \pm 3.8^{\circ}\right)$, distalization $(-1.1 \pm 1.1 \mathrm{~mm})$ and extrusion $(1.3 \pm 2.1 \mathrm{~mm})$, while in control group, the maxillary second molars showed mesial inclination $\left(1.6 \pm 5.2^{\circ}\right)$, mesialization $(0.9 \pm 1.8 \mathrm{~mm})$ and extrusion $(2.9 \pm 1.5 \mathrm{~mm})$ (Table 3$)$. 
Table 1 - Comparability between the groups.

\begin{tabular}{|c|c|c|c|c|c|c|c|}
\hline \multirow{2}{*}{ Variables (years) } & \multicolumn{2}{|c|}{ Group 1 (Experimental) } & \multicolumn{2}{|c|}{ Group 2 (Control) } & & \multirow{2}{*}{ p value } & \\
\hline & Mean & SD & Mean & SD & & & \\
\hline Initial age & 12.7 & 1.2 & 12.2 & 0.8 & & $0.145^{t}$ & \\
\hline Final age & 13.9 & 1.2 & 13.4 & 0.7 & & $0.139^{t}$ & \\
\hline Observation time & 1.2 & 0.3 & 1.2 & 0.3 & & $0.986^{t}$ & \\
\hline Sex & \multicolumn{2}{|c|}{ Group 1 (Experimental) } & \multicolumn{2}{|c|}{ Group 2 (Control) } & $\mathbf{P}$ & & $\mathrm{X}^{2}$ \\
\hline Male & \multicolumn{2}{|c|}{5} & \multicolumn{2}{|c|}{13} & ค 06 & & 354 \\
\hline Female & \multicolumn{2}{|c|}{17} & \multicolumn{2}{|c|}{9} & 0.00 & & 3.54 \\
\hline Malocclusion severity & \multicolumn{2}{|c|}{ Group 1 (Experimental) } & \multicolumn{2}{|c|}{ Group 2 (Control) } & $\mathbf{P}$ & & $x^{2}$ \\
\hline $1 / 4 \mathrm{Cl} \|$ & \multicolumn{2}{|c|}{4} & \multicolumn{2}{|c|}{5} & & & \\
\hline $1 / 2 \mathrm{Cl} \|$ & \multicolumn{2}{|c|}{16} & \multicolumn{2}{|c|}{14} & $0.80^{c}$ & & 0.44 \\
\hline $3 / 4 \mathrm{Cl} \mathrm{II}$ & \multicolumn{2}{|c|}{2} & \multicolumn{2}{|c|}{3} & & & \\
\hline
\end{tabular}

"Statistics: t, test t independent; c, chi-square test."

Table 2 - Comparison initial cephalometric values between groups

\begin{tabular}{|c|c|c|c|c|c|}
\hline \multirow{2}{*}{ Variables } & \multicolumn{2}{|c|}{ Group 1} & \multicolumn{2}{|c|}{ Group 2} & \multirow{2}{*}{ p Value } \\
\hline & Mean & SD & Mean & SD & \\
\hline SNA & 81.7 & 4.1 & 82.0 & 2.9 & 0.788 \\
\hline A-PTV & 47.8 & 2.4 & 48.9 & 1.9 & 0.098 \\
\hline SNB & 77.6 & 2.9 & 78.3 & 3.2 & 0.411 \\
\hline B-PTV & 46.2 & 4.5 & 46.9 & 4.1 & 0.596 \\
\hline Go-Gn & 70.3 & 3.7 & 71.6 & 3.7 & 0.263 \\
\hline Co-Gn & 104.2 & 4.4 & 106.3 & 4.7 & 0.143 \\
\hline ANB & 4.1 & 2.2 & 3.6 & 2.0 & 0.478 \\
\hline NAP & 6.2 & 5.6 & 5.6 & 5.3 & 0.754 \\
\hline FMA & 26.2 & 3.5 & 26.2 & 3.7 & 0.996 \\
\hline SN.GoGn & 31.6 & 3.6 & 31.1 & 4.9 & 0.668 \\
\hline LAFH & 60.4 & 4.5 & 60.7 & 3.3 & 0.222 \\
\hline SN.PP & 6.6 & 2.4 & 7.3 & 3.9 & 0.094 \\
\hline NS.GN & 67.0 & 2.9 & 66.5 & 3.4 & 0.979 \\
\hline 7.SN & 63.5 & 4.2 & 63.2 & 4.9 & 0.851 \\
\hline 7-PTV & 12.1 & 2.5 & 10.6 & 1.9 & $0.029 *$ \\
\hline 7-PP & 11.4 & 3.4 & 10.3 & 2.8 & 0.232 \\
\hline $6 . S N$ & 72.6 & 4.0 & 75.8 & 4.4 & $0.016^{*}$ \\
\hline 6-PTV & 21.2 & 3.0 & 20.1 & 2.4 & 0.190 \\
\hline 6-PP & 16.4 & 2.1 & 16.4 & 11.4 & 0.980 \\
\hline 4.SN & 83.8 & 5.3 & 82.3 & 5.0 & 0.335 \\
\hline 4-PTV & 36.3 & 3.2 & 35.3 & 2.2 & 0.271 \\
\hline 4-PP & 19.7 & 2.3 & 19.1 & 2.0 & 0.359 \\
\hline $1 . S N$ & 104.2 & 7.3 & 104.1 & 5.9 & 0.964 \\
\hline 1-PTV & 54.7 & 4.2 & 55.0 & 2.6 & 0.815 \\
\hline $1-P P$ & 26.7 & 2.7 & 26.3 & 2.3 & 0.674 \\
\hline NLA & 105.2 & 13.9 & 109.5 & 10.2 & 0.251 \\
\hline UL-E & 2.4 & 2.5 & 2.1 & 2.2 & 0.668 \\
\hline LL-E & 0.4 & 2.3 & 1.0 & 1.9 & 0.361 \\
\hline Overjet & 4.8 & 1.5 & 5.1 & 1.8 & 0.684 \\
\hline Overbite & 4.0 & 1.9 & 4.4 & 1.4 & 0.483 \\
\hline
\end{tabular}

*Statistically significant at $p<0.05$ 
Table 3 - Means and standard deviations of cephalometric changes after distalization (T0-T1)

\begin{tabular}{|c|c|c|c|c|c|}
\hline \multirow{2}{*}{ Variables } & \multicolumn{2}{|c|}{ Group 1 (Experimental) } & \multicolumn{2}{|c|}{ Group 2 (Control) } & \multirow{2}{*}{ P value } \\
\hline & Mean & SD & Mean & SD & \\
\hline SNA & 0.0 & 2.0 & 0.0 & 1.4 & 0.899 \\
\hline A-PTV & 0.4 & 1.7 & 1.0 & 1.3 & 0.203 \\
\hline SNB & 0.4 & 1.4 & -0.1 & 0.9 & 0.121 \\
\hline B-PTV & 1.0 & 2.0 & 0.9 & 2.1 & 0.853 \\
\hline Go-Gn & 1.3 & 1.5 & 1.6 & 1.3 & 0.513 \\
\hline Co-Gn & 2.1 & 2.9 & 2.1 & 2.3 & 0.968 \\
\hline ANB & -0.3 & 1.4 & 0.1 & 0.8 & 0.150 \\
\hline NAP & -1.0 & 3.1 & 0.0 & 2.0 & 0.173 \\
\hline FMA & 0.7 & 2.0 & -0.7 & 1.5 & $0.006^{*}$ \\
\hline SN.GoGn & -0.0 & 1.4 & 0.1 & 1.2 & 0.647 \\
\hline LAFH & 2.2 & 1.8 & 1.5 & 1.8 & 0.222 \\
\hline SN.PP & 0.0 & 1.5 & 0.7 & 1.4 & 0.094 \\
\hline NS.GN & 0.2 & 1.2 & 0.2 & 1.0 & 0.979 \\
\hline 7.SN & -6.6 & 3.8 & 1.6 & 5.2 & 0.000 * \\
\hline 7-PTV & -1.1 & 1.1 & 0.9 & 1.8 & $0.000^{*}$ \\
\hline 7-PP & 1.3 & 2.1 & 2.9 & 1.5 & $0.007^{*}$ \\
\hline $6 . S N$ & -2.4 & 5.2 & 0.1 & 4.4 & 0.079 \\
\hline 6-PTV & -1.2 & 1.4 & 1.1 & 1.6 & 0.000 * \\
\hline 6-PP & 0.6 & 1.8 & 1.0 & 1.2 & 0.495 \\
\hline 4.SN & -0.3 & 3.3 & -0.8 & 2.8 & 0.597 \\
\hline 4-PTV & 3.4 & 1.1 & 0.9 & 1.6 & $0.000 *$ \\
\hline 4-PP & 1.6 & 1.4 & 0.8 & 1.1 & 0.070 \\
\hline 1.SN & 4.3 & 4.7 & -0.3 & 3.0 & 0.000 * \\
\hline 1-PTV & 2.4 & 1.7 & 1.0 & 1.4 & $0.004^{*}$ \\
\hline 1-PP & 0.4 & 1.2 & 0.4 & 0.8 & 0.954 \\
\hline NLA & 1.7 & 15.5 & 0.9 & 7.2 & 0.842 \\
\hline UL-E & 0.1 & 1.3 & 0.5 & 0.7 & 0.235 \\
\hline LL-E & -0.0 & 1.4 & 0.5 & 0.8 & 0.105 \\
\hline Overjet & 1.5 & 1.1 & -0.0 & 0.7 & 0.000 * \\
\hline Overbite & -0.4 & 1.3 & -0.2 & 1.2 & 0.542 \\
\hline
\end{tabular}

*Statistically significant at $p<0.05$

In this study, the experimental group showed significant distalization of the first molars by a mean of $1.2 \pm 1.4 \mathrm{~mm}$ and the control group showed mesialization by a mean of $1.1 \pm 1.6 \mathrm{~mm}$. The maxillary first premolars mesialized in both groups, but in experimental group the mesialization was greater $(3.4 \pm 1.1 \mathrm{~mm})$. The maxillary incisors showed labial tipping of $4.3 \pm 4.7^{\circ}$ in experimental group and slight lingual tipping of $0.3 \pm 3.0^{\circ}$ in control group. In both groups, the maxillary incisors were protruded, but the protrusion was grater in experimental group $(2.4 \pm 1.7 \mathrm{~mm})$. There were no significant changes in the facial profile. The overjet increased significantly $1.5 \pm 1.1 \mathrm{~mm}$ in experimental group and practically did not change in the control group $(0.0 \pm 0.7 \mathrm{~mm})$. Overbite in both groups showed no significant changes (Table 3 ).

\section{DISCUSSION}

The strength of this study is the use of a control group, showing not only the effects with the Distal Jet appliance, but comparing it to a matched control group. The groups were comparable regarding initial and final ages, treatment/observation periods, sex distribution, malocclusion severity and initial cephalometric characteristics (Tables 1 and 2). 
The present sample included mostly patients with half-cusp Class II malocclusion, while most studies on the Distal Jet appliance did not mention the Class II malocclusion severity of their patients. ${ }^{17,18}$ Therefore, this has to be considered in the comparison to other studies.

The number of the patients could be greater. The initial experimental sample treated prospectively included 30 patients. However, some of them gave up the orthodontic treatment or moved out to other cities. And when the experimental and control samples were selected and matched, it was necessary to remove some patients from the sample, in order to make them comparable. ${ }^{24,25}$

There were no significant changes on the sagittal position of the maxillary and mandibular apical bases and in the maxillary-mandibular relationship, demonstrating that the Distal Jet does not influence the anteroposterior behavior of the skeletal bases. The skeletal results were already expected because the Distal Jet does not have skeletal effects, as found by others studies. ${ }^{6,16,17,26}$ Only the mandibular plane angle (FMA) showed a statistically significant increase in the experimental group, when compared to the control, but this change is temporary (Table 3). A possible explanation to the increase of FMA is the side-effect caused by extrusion, distalization mechanics and tipping of the maxillary second molars. When compared with control group, the maxillary second molars were less extruded, but these teeth were also distalized, therefore the FMA angle increased.

According to Kinzinger et $\mathrm{al},{ }^{27}$ the presence of the germ of the maxillary third molars in patients may influence the increase in the tipping of the second molars and consequently the increase of the FMA. However, the study of Vilanova et $\mathrm{al}^{21} \mathrm{did}$ not find significant increase of the FMA after treatment with Distal Jet followed by fixed appliance, but found significant increase of the SN.occlusal plane angle, though this alteration can be due to the use fixed appliances.

However, in this study, it was observed that a greater extrusion of the second molar was found in the control group and that this extrusion did not cause increase in the FMA on this group, contrary to the expected. The extrusion in control group was accompanied by mesial movement due to normal growth development, and this could explain why the FMA did not increase in the control group. Also, the change in the mandibular plane angle can be related with other factors such as facial growth pattern and the mandibular growth pattern of the patient. Therefore, more studies are necessary to identify the vertical skeletal alterations resulting of the treatment with Distal Jet.

The first molars showed a slight non-significant distal tipping, but a greater amount of distal tipping was observed in the second molars, when compared to the control group. The greater amount of distal tipping observed in the second molars could be due to the developmental stage of the third molars, which could influence the amount of tipping of the second molars. This is because, if the germ of the third molar is above the center of resistance of the second molar, it works as a rotation fulcrum and tends to distally tip the second molar. ${ }^{14}$ Besides, the entire sample presented the maxillary second molars erupted at the beginning of treatment, avoiding the excessive distal tipping of maxillary first molars. ${ }^{27,28}$

The maxillary second molars were moved distally $1.1 \mathrm{~mm}$ in the experimental group, while the control group showed a mesial movement of $0.9 \mathrm{~mm}$, which represents a $2.0-\mathrm{mm}$ correction in the Class II relationship (Table 3). There was $1.2 \mathrm{~mm}$ of maxillary first molar distalization in the experimental group, while the control group showed a mesial movement of $1.1 \mathrm{~mm}$, which represents a $2.3-\mathrm{mm}$ correction in Class II molar relationship (Table 3). A mesial movement in control group results from the growth of patients during the follow-up period.

These results were similar in other studies ${ }^{16,17,29}$ however, with a relatively smaller distalization, probably because all patients presented the germs of third molars, making the distalization difficult. The amount of molars distalization of this study was small. However, Ngantung et $\mathrm{a}^{16}$ and Nishii et $\mathrm{al}^{26}$ found similar results. Bolla et $\mathrm{a}^{17}$ found greater molar distalization than the present study. However, none of these studies mentioned the presence or not of erupted maxillary second molars, which prevents a direct comparison with the present results. 
The results of this study also showed a significant but small distalization of the maxillary molars. This reduced amount of distalization was caused by the presence of the germs of third molars, and the presence of erupted second molars, making the distalization more difficult. When treating patients with the Distal Jet appliance, one should observe the presence or not of the second and third molars. ${ }^{27,30}$ If more distalization is needed, it is indicated to use the appliance early, when the second molars are not erupted. If the tipping should be avoided, the presence of the second and third molars is desired. These characteristics should be observed in order to obtain the best results for each individual case to be treated.

According to Bolla et al, ${ }^{17}$ there is influence in the total space created during distalization of the anterior teeth anchorage loss. Thus, a relatively smaller distalization can be associated with the anchorage loss in the anterior teeth because the force used to distalize is dissipated in a mesial movement of the anterior teeth.

There was significant mesial movement of maxillary premolars, when compared to the control group (Table 3). There was significant protrusion and labial tipping of the maxillary incisors that were protruded by $2.4 \pm 1.7 \mathrm{~mm}$ and showed slight labial tipping of $4.3 \pm 4.7^{\circ}$. There was no significant change in the soft tissue component in the group treated with the Distal Jet. There was an increase of $1.5 \pm 1.1 \mathrm{~mm}$ in overjet in the experimental group, when compared to the control (Table 3 ). These results were also observed in other studies that used intraoral distalizers, including Distal Jet. $6,13-18,23,26,31,32$

There were no significant changes in the overbite and facial profile (Table 3). However, some studies showed that anchorage loss can influence the position of maxillary incisors and may cause changes in the profile. ${ }^{15,31,32}$

Intraoral distalizer effects with conventional and skeletal anchorage were studied in systematic review performed in 2013. ${ }^{6}$ This review concluded that both anchorage systems (conventional and skeletal) are effective for distalization, with skeletal anchorage presenting lower loss of anchorage. Therefore, the use Distal Jet appliance for the treatment of the Class II malocclusion is a viable alternative, especially when some effects of the appliance can favor the treatment. For example, in Class II, division 2 malocclusion, the maxillary incisors need to be protruded and distal jet appliance promotes this protrusion, or when the miniscrew cannot be used.

Other two systematic reviews were performed to evaluate the quantitative effects of the conventional pendulum appliance and modified pendulum appliance and of miniscrew-supported appliances for maxillary molar distalization in Class II malocclusions. ${ }^{33,34}$ However, both studies present simple descriptive and stratified comparisons and reported limitations, due to heterogeneity among the studies, that impaired the realization of meta-analysis.

Currently, there are several orthodontic distalization appliances. Studies like this are important for the orthodontist to know and understand the effects of a specific appliance.

\section{CONCLUSIONS}

The use of Distal Jet appliance compared to a control group can cause increase in mandibular plane angle, distal inclination, distalization and extrusion of the maxillary second molars, distalization of the first molars, mesialization of the maxillary first premolars, and labial inclination and protrusion of the maxillary incisors, leading to an increase in the overjet.

\section{Authors contribution (ORCID (D))}

Rachelle Simões Reis (RSR): 0000-0001-9966-5763 José F. C. Henriques (JFCH): 0000-0001-6546-1631 Guilherme Janson (GJ): 0000-0001-5969-5175 ${ }^{\circ}$

Karina M. S. Freitas (KMSF): 0000-0001-9145-6334 Wilana Moura (WM): 0000-0003-0567-3717 ${ }^{\circ}$

Conception or design of the study: RSR, JFCH, GJ. Data acquisition, analysis or interpretation: RSR, JFCH, GJ, KMSF, WM. Writing the article: KMSF, WM. Critical revision of the article: RSR, JFCH, GJ, KMSF, WM. Final approval of the article: RSR, JFCH, GJ, KMSF, WM. 
1. Caprioglio A, Cozzani M, Fontana M. Comparative evaluation of molar distalization therapy with erupted second molar: Segmented versus Quad Pendulum appliance. Prog Orthod. 2014;15(1):49

2. Kuroda S, Hichijo N, Sato M, Mino A, Tamamura N, Iwata M, et al. Long-term stability of maxillary group distalization with interradicular miniscrews in a patient with a Class II Division 2 malocclusion. Am J Orthod Dentofacial Orthop. 2016 June;149(6):912-22.

3. Mariani L, Maino G, Caprioglio A. Skeletal versus conventional intraoral anchorage for the treatment of class II malocclusion: dentoalveolar and skeletal effects. Prog Orthod. 2014:15:43

4. Bowman SJ. The effect of vibration on molar distalization. J Clin Orthod. 2016 Nov; $50(11): 683-93$

5. Ravera S, Castroflorio T, Garino F, Daher S, Cugliari G, Deregibus A. Maxillary molar distalization with aligners in adult patients: a multicenter retrospective study. Prog Orthod. 2016:17:12

6. Grec RH, Janson G, Branco NC, Moura-Grec PG, Patel MP, Henriques JFC. Intraoral distalizer effects with conventional and skeletal anchorage: a meta-analysis. Am J Orthod Dentofacial Orthop. 2013 May;143(5):602-15.

7. Cozzani M, Pasini M, Zallio F, Ritucci R, Mutinelli S, Mazzotta L, et al Comparison of maxillary molar distalization with an implant-supported distal jet and a traditional tooth-supported distal jet appliance. Int J Dent. 2014:2014:937059.

8. Yamaguchi M, Inami T, Ito K, Kasai K, Tanimoto Y. Mini-implants in the anchorage armamentarium: new paradigms in the orthodontics. Int J Biomater. 2012:2012:394121

9. Roncone CE. Complications encountered in temporary orthodontic anchorage device therapy. Semin Orthod. 2011:17(2):168-79.

10. Reynders R, Ronchi L, Bipat S. Mini-implants in orthodontics: a systematic review of the literature. Am J Orthod Dentofacial Orthop. 2009 May:135(5):564.e1-19.

11. Brandão LBC, Mucha JN. Grau de aceitação de mini-implantes por pacientes em tratamento ortodôntico-estudo preliminar. Rev Dental Press Ortod Ortop Facial. 2008;13(5):118-27.

12. Kinzinger GS, Eren M, Diedrich PR. Treatment effects of intraoral appliances with conventional anchorage designs for non-compliance maxillary molar distalization: a literature review. Eur J Orthod. 2008 Dec;30(6):558-71

13. Carano A, Testa M, Bowman SJ. The distal jet simplified and updated. J Clin Orthod. 2002:36:586-90.

14. Brickman CD, Sinha PK, Nanda RS. Evaluation of the Jones jig appliance for distal molar movement. Am J Orthod Dentofacial Orthop. 2000;118(5):526-34

15. Bussick TJ, McNamara JA. Dentoalveolar and skeletal changes associated with the pendulum appliance. Am J Orthod Dentofacial Orthop. 2000;117(3):333-43.

16. Ngantung V, Nanda RS, Bowman SJ. Posttreatment evaluation of the distal jet appliance. Am J Orthod Dentofacial Orthop. 2001 Aug:120(2):178-85

17. Bolla E, Muratore F, Carano A, Bowman SJ. Evaluation of maxillary molar distalization with the distal jet: a comparison with other contemporary methods. Angle Orthod. 2002 Oct;72(5):481-94.
18. Chiu PP. McNamara JA, Franchi L. A comparison of two intraoral molar distalization appliances: distal jet versus pendulum. Am J Orthod Dentofacial Orthop. 2005 Sept;128(3):353-65

19. Ferguson DJ, Carano A, Bowman SJ, Davis EC, Gutierrez Vega ME, Lee SH. A comparison of two maxillary molar distalizing appliances with the distal jet. World J Orthod. 2005 Winter;6(4):382-90.

20. Marure PS, Patil RU, Reddy S, Prakash A, Kshetrimayum N, Shukla R The effectiveness of pendulum, K-loop, and distal jet distalization techniques in growing children and its effects on anchor unit: a comparative study. J Indian Soc Pedod Prev Dent. 2016 OctDec;34(4):331-40.

21. Vilanova L, Henriques JFC, Janson G, Patel MP, Reis RS, Aliaga-Del Castillo A. Class II malocclusion treatment effects with Jones Jig and Distal Jet followed by fixed appliances. Angle Orthod. 2018 Jan; 88(1):10-9

22. Patel MP, Henriques JFC, Almeida RR, Pinzan A, Janson G, Freitas MR. Comparative cephalometric study of Class II malocclusion treatment with Pendulum and Jones jig appliances followed by fixed corrective orthodontics. Dental Press J Orthod. 2013:18(6):58-64

23. Carano A, Testa M. The distal jet for upper molar distalization. J Clin Orthod. 1996 July:30(7):374-80

24. Kirkwood BR, Sterne JAC. Essential medical statistics. Hoboken: John Wiley \& Sons; 2010

25. Hill AB. Principles of medical statistics. [S.I.]: Hodder Education Publishers; 1971

26. Nishii $Y$, Katada H, Yamaguchi H. Three-dimensional evaluation of the distal jet appliance. World J Orthod. 2002;3(4):321-7.

27. Kinzinger GS, Fritz UB, Sander FG, Diedrich PR. Efficiency of a pendulum appliance for molar distalization related to second and third molar eruption stage. Am J Orthod Dentofacial Orthop. 2004 Jan;125(1):8-23.

28. Bondemark L, Kurol J. Distalization of maxillary first and second molars simultaneously with repelling magnets. Eur J Orthod. 1992 Aug:14(4):264-72

29. Gianelly AA, Vaitas AS, Thomas WM, Berger DG. Distalization of molars with repelling magnets. J Clin Orthod. 1988 Jan;22(1):40-4.

30. Karlsson I, Bondemark L. Intraoral maxillary molar distalization: movement before and after eruption of second molars. Angle Orthod. 2006 Nov:76(6):923-9

31. Haydar S, Uner O. Comparison of Jones jig molar distalization appliance with extraoral traction. Am J Orthod Dentofacial Orthop. 2000 Jan:117(1):49-53

32. Toroglu MS, lu M, Uzel I, am O, Hancioglu ZB, lu Z. Cephalometric evaluation of the effects of pendulum appliance on various vertical growth patterns and of the changes during short-term stabilization. Clin Orthod Res. 2001 Feb:4(1):15-27

33. Al-Thomali Y, Basha S, Mohamed RN. Pendulum and modified pendulum appliances for maxillary molar distalization in Class II malocclusion a systematic review. Acta Odontol Scand. 2017 Aug:75(6):394-401.

34. Mohamed RN, Basha S, Al-Thomali Y. Maxillary molar distalization with Miniscrew-supported appliances in Class 11 malocclusion: a systematic review. Angle Orthod. 2018 July:88(4):494-502. 